\title{
The EACVI Echo Handbook
}

\section{- ilustrirani podsjetnik za interniste i kardiologe}

\section{The EACVI Echo Handbook \\ - an illustrated field guide for internists and cardiologists}

\author{
Edited by Patrizio Lancellotti, Bernard Cosyns \\ European Society of Cardiology publications \\ Publisher: Oxford University Press \\ Paperback; 616 Pages \\ Published: November 2015 \\ Published online: January 2016 \\ ISBN: 9780198713623 \\ DOI: http://dx.doi.org/10.1093/med/9780198713623.001.0001
}

Riječ je o iznimno grafički dotjeranom podsjetniku iz područja ehokardiografije koji na prvi pogled osvaja praktičnim, džepnim formatom. Uredili su ga prof. Lancellotti (voditelj Europskog udruženja za kardiovaskularno oslikavanje u mandatu od 2012. do 2014. godine) i prof. Cosyns (voditelj Nukleusa Ehokardiografske sekcije pri Europskom udruženju za kardiovaskularno oslikavanje). Za moderan način prezentacije koji će pomoći

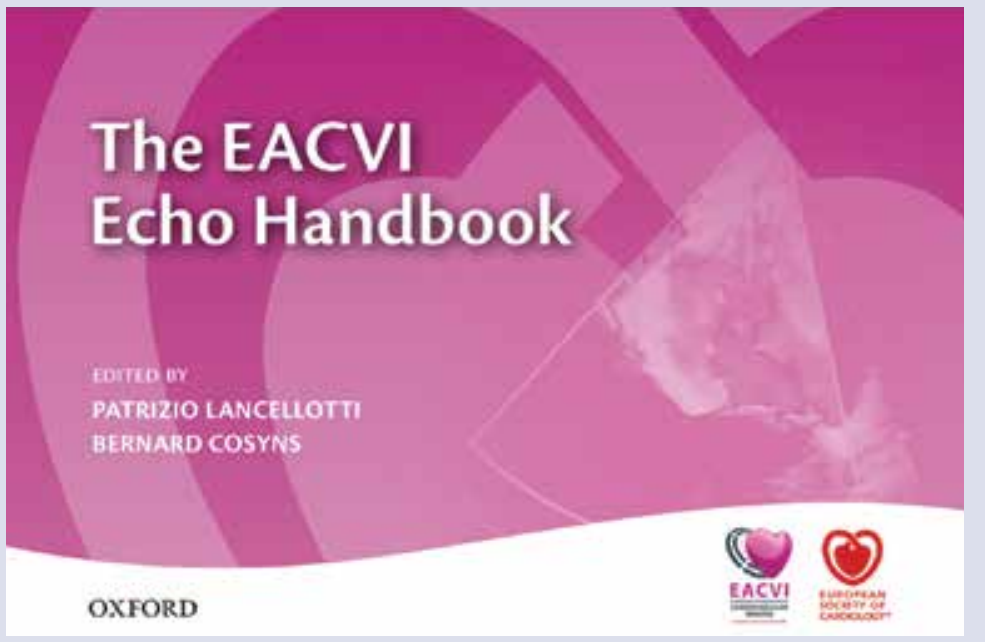

This well-polished echocardiography field guide is immediately attractive due to its practical pocket-size. It is edited by Prof. Lancellotti (Head of the European Association of Cardiovascular Imaging in the 2012-2014 term) and Prof. Cosyns (Nucleus Head of the Echocardiographic section of the European Association of Cardiovascular Imaging). The modern presentation that will help train the skills used in učenju vještine ehokardiografskog pregleda, uz 30 vodećih eksperata, odgovorno je i pet urednika sekcija (prof. Donal, dr. Garbi, dr. Jurcut, dr. Monney i prof. Šeparović Hanževački).

Strukturu knjige čini 17 poglavlja koja slijede logiku svakodnevnog rada u ehokardiografskom laboratoriju. Izvrsna razrada pojedinih problemskih cjelina kojima se na logičan i lako razumljiv način integriraju opsežna znanja iz stručne literature korak je naprijed važan za edukaciju svakog internista i kardiologa iz područja kardiovaskularnog oslikavanja. echocardiographic examinations is the result of the efforts
of 30 leading experts and five section editors (Prof Donal, Dr
Garbi, Dr Jurcut, Dr Monney, and Prof Šeparović Hanževački).
The book is structured into 17 chapters that follow the logic
of everyday practice in an echocardiographic laboratory. The
elaboration of individual thematic areas is excellent, integrat-
ing extensive insights from the expert literature into a logical
and easily-intelligible way, and represents a step forward that
is important to the education of every internist and cardiolo-
gist in the field of cardiovascular imaging.

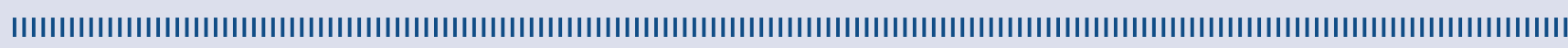
Assist. Prof. Mario Ivanuša, MD, PhD, FESC

Institute for Cardiovascular Prevention and Rehabilitation, Zagreb, Croatia / E-mail: mivanusa@gmail.com

CITATION: Cardiol Croat. 2016;11(7):252. | DOI: http://dx.doi.org/10.15836/ccar2016.252

RECEIVED: May 15, 2016 | ACCEPTED: May 24, 2016

ORCID: Mario Ivanuša, http://orcid.org/0000-0002-6426-6831 